\title{
PENGARUH POTENSI PAJAK DAERAH TERHADAP PENDAPATAN ASLI DAERAH (PAD) DAN KAPASITAS FISKAL DI KABUPATEN/KOTA DI JAWA BARAT
}

\author{
LISNA LISNAWATI \\ STIE SEBELAS APRIL SUMEDANG \\ JALAN ANGKREK SITU NO. 90 SUMEDANG \\ Email: watilisna879@gmail.com
}

\begin{abstract}
ABSTRAK
Penelitian ini bertujuan untuk menganalisis pengaruh Potensi Pajak Daerah terhadap Pendapatan Asli Daerah dan Kapasitas Fiskal di Kabupaten/Kota di Jawa Barat tahun 2012 sampai 2016. Data yang digunakan dalam penelitian ini diperoleh dari Laporan Target Pajak Daerah, Laporan Realisasi Anggaran dan Indek Kapasitas Fiskal (IKF) periode 2012 sampai dengan 2016 yang diterbitkan oleh Direktorat Jendral Perimbangan Keuangan (DJPK) Kementrian Keuangan Republik Indonesia. Metode penelitian yang digunakan dalam penelitian ini adalah metode penelitian deskriptif yang menggunakan pendekatan analisis kuantitatif. Tujuan penelitian deskriptif ini adalah untuk membuat deskripsi mengenai fakta-fakta, sifat, hubungan serta pengaruh antar fenomena yang diselidiki. Instrument penelitian yang digunakan adalah Regresi Sederhana yang merupakan salah satu metode analisis bivariate. Hasil penelitian dan pengujian hipotesis menunjukan bahwa Potensi Pajak Daerah berpengaruh signifikan terhadap Pendapatan Asli Daerah dan bahwa Potensi Pajak Daerah tidak berpengaruh secara signifikan terhadap Kapasitas Fiskal.
\end{abstract}

Kata kunci: Potensi Pajak Daerah, Pendapatan Asli Daerah dan Kapasitas Fiskal.

\section{PENDAHULUAN}

Bergulirnya otonomi daerah yang diberlakukan di indonesia memberikan efek domino yang saling keterkaitan. Desentralisasi yang digulirkan memberikan kewenangan bagi daerah untuk mengelola rumah tangga daerahnya sendiri. Namun hal tersebut belum menjamin daerah lebih mandiri dalam pengelolaan keuangannya, karena banyak faktor yang bisa mempengaruhi kemandirian suatu daerah yaitu bisa dilihat dari segi pendapatan daerah dan belanja daerahnya itu sendiri. Menurut Mardiasmo (2002:24), "otonomi yang diberikan kepada kabupaten dan kota dilaksanakan dengan memberikan kewenangan yang luas, nyata dan bertanggung jawab kepada pemerintah daerah secara proporsional dan pemanfaatan sumber daya nasional yang berkeadilan serta perimbangan keuangan pusat dan daerah".

Ketimpangan antara daerah dengan sumber daya yang melimpah dengan daerah yang minim sumber daya mengakibatkan ketidak meratanya

(20) UTama UISNA LISNAWATI 1249


pembangunan di daerah. Hal tersebut mengakibatkan adanya konflik horizontal imbalance (ketimpangan antar daerah). Apalagi untuk daerah-daerah pemekaran yang mereka diibaratkan bayi yang baru lahir dan melihat dunia, belum tahu apaapa dan perlu proses menjadi anak-anak dan dewasa yang kemandiriannya memerlukan waktu dan proses yang tidak sebentar. Melihat hal tersebut peran serta pemerintah pusat untuk tetap ikut terlibat dan berperan baik dari segi financial maupun non financil masih menjadi tumpuan utama penyeimbang pembangunan daerah-daerah. Sehingga wajar jika ketimpangan antar daerah meningkatkan ketergantungan pemerintah daerah kepada pemerintah pusat. Ketergantungan pemerintah daerah terhadap pemerintah pusat dapat tercermin dari besarnya transfer dari pusat terhadap daerah dalam hal ini pemerintah Kabupaten/Kota dalam bentuk Dana Alokasi Umum. Dana Alokasi Umum (DAU) mencerminkan besarnya fiskal gap yang merupakan selisih dari kebutuhan fiskal dengan kapasitas fiskal suatu daerah. "Kebutuhan Fiskal adalah kebutuhan pendanaan daerah untuk melaksanakan fungsi dasar umum." (Jaka Sriyana, 2012:27). Sedangkan Kapasitas Fiskal mencerminkan kemampuan daerah dalam memperoleh sumber pendapatan yang bisa digunakan untuk memenuhi kebutuhan dan belanja daerah dalam rangka menyediakan pelayanan publik (expenditure needs).

Kapasitas fiskal dijadikan patokan untuk melihat seberapa besar potensi ekonomi yang bisa digali dan dimanfaatkan sebagai sumber pendapatan daerah. Karena seperti yang kita ketahui bahwa kendala utama yang dihadapi dalam pelaksanaan otonomi daerah yaitu terbatasnya sumber-sumber pembiayaan untuk pelaksanaan desetralisasi sehingga kemandirian daerah dalam menjalankan rumah tangganya belum bisa berjalan maksimal. Salah satu indikator ketercapaian kemandirian daerah terhadap ketergantungan pemerintah pusat salah satunya bisa dilihat dari peta kapasitas fiskal dan indek kapasitas fiskal. Jawa Barat sebagai Provinsi yang secara wilayah berada di pulau jawa yang merupakan daerah penyangga ibu kota negara ternyata masih memiliki predikat dengan kapasitas fiskal yang rendah yaitu tingkat ketercapaian IKF (Indek Kapasitas Fiskal) hanya 0,30. Bila dibandingkan dengan DKI Jakarta dimana IKF (Indek Kapasitas Fiskal) mencapai 6,36 dengan predikat sangat tinggi, sangatlah terlihat kesenjangannya antara kedua provinsi yang saling berdekatan itu. Selain itu apabila diperbandingkan dengan Provinsi banten yang merupakan Provinsi baru, Banten memiliki IKF(Indek Kapasitas Fiskal) dengan predikat sedang. Lalu apa yang salah dengan Jawa Barat ? apakah potensi sumber pendapatan memang tidak ada atau potensi nya ada bahkan banyak tetapi penggalian dan pemanfaatan potensi nya yang memang belum maksimal. Di bawah ini disajikan data Indek Kapasitas Fiskal dan Predikat beberapa Provinsi yang ada di pulau Jawa berdasarkan data yang dirilis oleh Menteri Keuangan RI dalam PMK No. 37/PMK.07/2016 tentang Peta Kapasitas Fiskal.

Ada sekitar 17 Kabupaten dari 26 Kabupaten/Kota atau sekitar $65,38 \%$ yang memiliki IKF dengan predikat rendah. Itu bukan merupakan prestasi yang membanggakan bagi pemerintah Provinsi Jawa Barat. Apa yang melatarbelakangi hal tersebut, pasti ada faktor-faktor yang mengakibatkan kapasitas fiskal daerah berada pada posisi rendah, sedang dan tinggi.

Salah satu tujuan utama pemerintah adalah meningkatkan kesejahteraan seluruh rakyat. Sehubungan dengan hal tersebut pemerintah berupaya untuk 
mewujudkan keseimbangan fiskal dengan mempertahankan kemampuan keuangan negara yang bersumber dari pendapatan asli daerah dan sumbersumber lainnya guna memenuhi kebutuhan masyarakat.

Jika dilihat dari Laporan dan Realisasi Anggaran (LRA) yang disusun oleh beberapa Pemerintah Provinsi dan Kabupaten/kota, menunjukan bahwa jumlah pendapatan yang bersumber dari daerahnya belum bisa menutupi APBD daerahnya, sehingga untuk menutupi kekurangan tersebut pemerintah Kabupaten/kota mengandalkan dana transferan baik dana transferan dari pemerintah pusat maupun provinsi.

Realita yang terjadi sekarang adalah kontribusi dana perimbangan daerah pemerintah pusat terhadap pemerintah daerah sangat tidak proporsional. Artinya bahwa pemerintah pusat mendanai daerah dalam jumlah yang besar dibanding kemandirian pemerintah daerah itu sendiri dalam membiayai pembangunan dan belanjanya. Berdasarkan data yang dirilis dalam Budget in Brief 2016 oleh Direktorat Jendral Perimbangan Keuangan Kementrian Keuangan RI tahun 2016 menyatakan bahwa dana perimbangan pusat mendominasi jumlah pendapatan yang diperoleh daerah selama tahun 2016 adalah sebesar $64 \%$.

Dalam data di atas jelaslah sudah bahwa Pendapatan Asli Daerah beberapa Kabupaten/Kota di Indonesia masih perlu digali dan dikembangkan. Untuk menaikan Pendapatan asli daerah sumber yang bisa di gali adalah Pajak Daerah dan Retribusi daerah. Pemerintah daerah bisa melakukan perluasan atas pajak dan retribusi yang bisa digali dan di jadikan potensi sumber pendapatan daerah. Berdasarkan latar belakang diatas penulis tertarik untuk membahas "PENGARUH POTENSI PAJAK DAERAH TERHADAP PENDAPATAN ASLI DAERAH (PAD) DAN KAPASITAS FISKAL DI KABUPATEN/KOTA DI JAWA BARAT".

Adapun rumusan masalah dalam penelitian ini adalah sebagai berikut:

1. Apakah terdapat pengaruh potensi pajak daerah terhadap Pendapatan Asli Daerah (PAD) di beberapa Kabupaten/kota di Provinsi jawa Barat?

2. Apakah terdapat pengaruh potensi pajak daerah terhadap Kapasitas Fiskal di beberapa Kabupaten/Kota di Provinsi Jawa Barat?

Tujuan yang ingin dicapai dari penelitian ini adalah:

1. Menguji pengaruh potensi pajak terhadap Pendapatan Asli Daerah di beberapa Kabupaten/ Kota di Provinsi Jawa Barat.

2. Menguji pengaruh potensi pajak terhadap kapasitas fiskal di beberapa Kabupaten/kota di Provinsi Jawa Barat.

\section{TINJAUAN PUSTAKA \\ 2.2 Kapasitas Fiskal}

Compson dan Navratil (1997: 3-4) mendefinisikan "kapasitas fiskal sebagai kemampuan suatu daerah untuk meningkatkan penerimaan dari berbagai sumber daya yang dimilikinya".

Faktor-faktor yang bisa mempengaruhi kapasitas fiskal adalah kapasitas industri, kekayaan sumber daya alam, dan pendapatan perseorangan. Kapasitas fiskal sering dikaitkan pula dengan sektor tertentu, misalnya sebagai kemampuan pemerintah daerah untuk membiayai pendidikan dari sumber-sumber pajak

(20) UJama


yang tersedia. Cara yang bisa digunakan dalam pengukuran untuk mengestimasi kapasitas fiskal suatu daerah dan masing-masing cara memiliki keterbatasan. Lebih lanjut dikemukakan bahwa terdapat dua kategori umum untuk pengukuran kapasitas fiskal, yaitu indeks sumber daya ekonomi atau pendapatan daerah dan indeks penerimaan relatif yang dapat ditingkatkan di bawah suatu standar kebijakan fiskal. Sementara itu pendapat lain mengenai kapasitas fiskal adalah sebagai berikut:

Gerry dan Mickiewicz (2006) mendefinisikan "Kapasitas fiskal secara singkat sebagai kemampuan daerah untuk meningkatkan pajak secara efisien.'Definisi kapasitas fiskal dikaitkan secara langsung dengan kemampuan keuangan daerah yang mencakup provinsi, kabupaten, dan kota. Pada pasal 1 butir 1 PMK No. 37/PMK.07/2016 dituliskan bahwa:

"Kapasitas fiskal adalah gambaran kemampuan keuangan masingmasing daerah yang dicerminkan melalui penerimaan umum Anggaran Pendapatan dan Belanja Daerah (tidak termasuk dana alokasi khusus, dana darurat, dana pinjaman lama, dan penerimaan lain yang penggunaannya dibatasi untuk membiayai pengeluaran tertentu)

untuk membiayai tugas pemerintahan setelah dikurangi belanja pegawai dan dikaitkan dengan jumlah penduduk miskin."

Sementara itu dalam pasal 1 butir 2 PMK No.37/PMK.07/2016 dituliskan bahwa: "Peta Kapasitas Fiskal Daerah yang selanjutnya disebut Peta Kapasitas Fiskal adalah gambaran kapasitas fiskal yang dikelompokkan berdasarkan indeks kapasitas fiskal daerah."

Secara umum, terdapat dua jenis kapasitas fiskal, yaitu kapasitas fiskal absolut dan kapasitas fiskal relatif, sebagai berikut:

1. Kapasitas Fiskal Absolut

Kapasitas fiskal absolut merupakan kapasitas fiskal jangka panjang (longrun). Menurut Samuel Aaron Gurwitz Kapasita Fiskal adalah: "the maximum present value of revenue that can be raised over time by the governments serving agiven area". Pengertiannya kurang lebih adalah penerimaan maksimum berkelanjutan sebagai jumlah penerimaan pajak yang dapat diraih oleh suatu kota atau daerah pada periode yang tidak terbatas, tanpa mengurangi tingkat basis pajak, konsep ini mengindikasikan prinsip netralitas.

2. Kapasitas Fiskal Relatif

Kapasitas fiskal relatif merupakan konsep yang berbeda, karena mengacu pada periode tertentu, yaitu periode fiskal saat ini. Perhitungannya ditentukan oleh standarisasi yurisdiksi nilai pendapatan, kekayaan, atau ukuran produktivitas ekonomi lainnya per kapita. Indikator-indikator yang digunakan di dalam kapasitas fiskal relatif meliputi pendapatan, nilai properti, dan rata-rata pungutan pajak penjualan. Konsep ini digunakan secara luas oleh para penganut aliran keuangan publik.

Peta Kapasitas Fiskal dapat digunakan untuk:

1. Pengusulan Pemerintah Daerah sebagai penerima hibah

2. Penilaian atas usulan pinjaman daerah

3. Penentuan besaran dana pendamping, jika dipersyaratkan 
4. Hal lain yang diatur secara khusus dalam peraturan perundangundangan.

\section{Perhitungan Peta Kapasitas Fiskal \\ $\mathrm{K} F=\underline{(P A D+D A U+D B H+O T S U S+T R A N S F E R P R O V+L P)-B P}$ Jumlah Penduduk Miskin}

di mana:

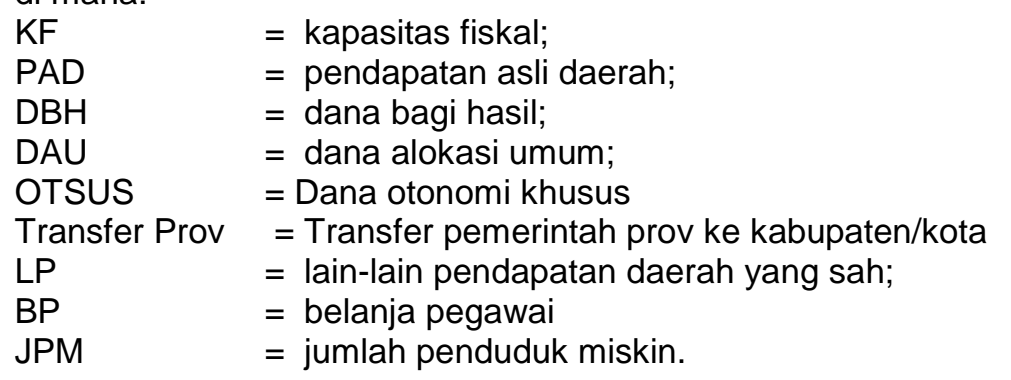

Penghitungan Indeks Kapasitas Fiskal Daerah Provinsi dan Daerah Kabupaten / Kota didasarkan pada formula sebagai berikut:

Keterangan:

$$
\mathrm{IKF}=\frac{K F}{(\Sigma K F) / n}
$$

IKF = Indeks Kapasitas Fiskal suatu Daerah

$\mathrm{KF}=$ Kapasitas Fiskal suatu Daerah

$\mathrm{n}$ = Jumlah provinsi,dan kabupaten /kota

Berdasarkan perhitungan kapasitas fiskal untuk masing-masing daerah, selanjutnya dapat dihitung indeks kapasitas fiskal daerah (IKF). IKF suatu provinsi diperoleh dengan membagi kapasitas fiskal provinsi yang bersangkutan dengan rata-rata kapasitas fiskal seluruh provinsi di Indonesia. Dengan cara perhitungan yang sama, IKF suatu kabupaten/kota dihasilkan dengan membagi kapasitas fiskal kabupaten/kota tertentu dengan rata-rata kapasitas fiskal semua kabupaten/kota di Indonesia.

Di dalam pasal 4 butir (6) PMK No. 37/PMK.07/2016 disebutkan bahwa berdasarkan perhitungan IKF, maka daerah dapat dikelompokkan ke dalam empat kategori, yaitu:

1. Daerah yang IKF-nya lebih dari atau sama dengan 2 (IKF $\geq 2$ ) merupakan daerah yang termasuk kategori Kapasitas Fiskal Sangat Tinggi;

2. Daerah yang IKF-nya antara lebih dari atau sama dengan 1 sampai kurang dari $2(1 \leq \mathrm{IKF}<2)$ merupakan daerah yang termasuk kategori Kapasitas Fiskal Tinggi;

3. Daerah yang IKF-nya antara lebih dari 0,5 sampai kurang dari $1(0,5<$ IKF < 1) merupakan daerah yang termasuk kategori Kapasitas Fiskal Sedang; dan

4. Daerah yang IKF-nya kurang dari atau sama dengan 0,5 (IKF $\leq 0,5)$ merupakan daerah yang termasuk kategori Kapasitas Fiskal Rendah. 
Kapasitas fiskal menunjukkan kemampuan daerah dalam membiayai sendiri kegiatan pemerintahan, pembangunan, dan pelayanan kepada masyarakat yang telah membayar pajak dan retribusi sebagai sumber pendapatan yang diperlukan daerah. Jika Mengacu pada Peraturan Menteri Keuangan tersebut maka komponen Kapasitas fiskal adalah : Pendapatan Asli Daerah ( PAD ), Dana Alokasi Umum ( DAU ) dan Dana Bagi Hasil (DBH).

\subsection{Pendapatan Asli Daerah (PAD)}

Pendapatan asli Daerah (PAD) merupakan sumber pendapatan daerah yang dapat dijadikan sebagai salah satu tolak ukur bagi kinerja perekonomian suatu daerah. "Pendapatan Asli daerah, merupakan pendapatan daerah yang bersumber dari daerah itu sendiri. Termasuk dalam pendapatan jenis ini adalah pajak daerah, retribusi daerah, hasil

pengelolaan kekayaan daerah yang dipisahkan, dan lain-lain PAD yang sah." (Deddi Nordiawan, 2012:181).

Pendapat lain mengatakan bahwa pendapatan daerah adalah: "Pendapatan Asli Daerah (PAD) adalah penerimaan yang diperoleh daerah dari sumbersumber dalam wilayah sendiri yang dipungut berdasarkan peraturan sesuai dengan peraturan perundang-undangan yang berlaku." (M. Aries Djaenuri, 2012:88). Pendapatan yang diperoleh dari wilayah sendiri adalah mencakup lingkup daerah itu sendiri baik daerah dalam lingkup Provinsi, Kabupaten/kota atau lingkup yang lebih kecil dalam wilayah tersebut.

Sementara itu menurut Warsito (2001:128) Pendapatan Asli Daerah adalah sebagai berikut: "Pendapatan asli daerah (PAD) adalah pendapatan yang bersumber dan dipungut sendiri oleh pemerintah daerah. Sumber PAD terdiri dari: pajak daerah, restribusi daerah, laba dari badan usaha milik daerah (BUMD), dan pendapatan asli daerah lainnya yang sah".

Berdasarkan Undang-Undang Nomor 23 Tahun 2014 tentang Pemerintahan Daerah dan Undang-Undang Nomor 33 Tahun 2004 tentang Perimbangan Keuangan antara Pemerintah Pusat dan Pemerintah Daerah: "Pendapatan Asli Daerah (PAD) adalah pendapatan yang diperoleh daerah yang dipungut berdasarkan peraturan daerah sesuai dengan peraturan perundang-undangan, meliputi:

1. Pajak daerah;

2. Retribusi daerah;

3. Hasil pengelolaan kekayaan daerah yang dipisahkan;

4. Lain-lain PAD yang sah."

Pajak daerah, retribusi daerah dan hasil pengelolaan kekayaan daerah yang dipisahkan ditetapkan dengan undang-undang dimana pelaksanaannya di daerah diatur lebih lanjut dengan Peraturan Daerah (PERDA). Sedangkan yang dimaksud dengan lain-lain pendapatan PAD yang sah terdiri dari:

1. Hasil penjualan kekayaan daerah yang tidak dipisahkan

2. Jasa giro

3. Pendapatan bunga

4. Keuntungan selisih nilai tukar rupiah terhadap mata uang asing, dan

5. Komisi, potongan, ataupun bentuk lain sebagai akibat dari penjualan dan/atau pengadaan barang dan/atau jasa oleh daerah. 
Tujuan Pendapatan Asli Daerah (PAD) terdapat dalam pasal 3 UU No. 33 tahun 2004 tentang perimbangan keuangan antara pusat dan daerah sebagai berikut: "PAD bertujuan memberikan kewenangan kepada Pemerintah Daerah untuk mendanai pelaksanaan otonomi daerah sesuai dengan potensi Daerah sebagai perwujudan Desentralisasi."

\subsection{Potensi Pajak Daerah}

Menurut pendapat Majdi Potensi dapat didefinisikan sebagai "Suatu kemampuan, kesanggupan, kekutan ataupun daya yang mempunyai kemungkinana untuk bisa dikembangkan lagi menjadi bentuk yang lebih besar." (Majdi:2007).

Menurut Davey (2011), Terdapat empat kriteria untuk menilai potensi pajak daerah yaitu :

1. Kecukupaan dan Elastisitas

Adalah kemampuan untuk menghasilkan tambahan pendapatan agar dapat menutup tuntutan yang sama atas kenaikan pengeluaran pemerintah dan dasar pengenaan pajaknya berkembang secara otomatis.

2. Keadilan

Bahwa pengeluaran pemerintah harus dipikul oleh semua golongan masyarakat sesuai dengan kekayaan dan kesanggupan masing-masing golongan.

3. Kemampuan administrasi

Bahwa waktu yang diberikan dan biaya yang dikeluarkan dalam menetapkan dan memungut pajak sebanding dengan hasil yang mampu dicapai.

4. Kesepakatan politis

Diperlukan dalam pengenaan pajak, penetapan struktur tarif, memutuskan siapa yang harus membayar dan bagaimana pajak tersebut ditetapkan dan memberikan sanksi bagi yang melanggarnya.

\section{METODE PENELITIAN}

3.1 Desain Penelitian

Dalam penelitian ini penulis menggunakan metode penelitian deskriptif yang menggunakan pendekatan analisis kuantitatif. Menurut M. Nazir (2003:54), "metode deskriptif yaitu metode yang digunakan dalam meneliti status kelompok manusia, suatu objek, suatu kondisi, suatu sistem pemikiran, ataupun suatu peristiwa pada masa sekarang. Tujuan penelitian deskriptif ini adalah untuk membuat deskripsi mengenai fakta-fakta, sifat, hubungan serta pengaruh antar fenomena yang diselidiki."

\subsection{Jenis dan Sumber Data}

Data dalam penelitian ini adalah menggunakan data sekunder. Pengertian dari data sekunder menurut Sugiyono adalah "Sumber data yang tidak langsung memberi kan data kepada pengumpul data, misalnya lewat orang lain atau lewat dokumen."(2010:137). Data sekunder yang digunakan adalah data yang diambil selama 5 tahun yaitu tahun 2012 sampai dengan 2016 baik untuk data potensi pajak, pendapatan asli daerah maupun kapasitas fiskal. Data-data tersebut 
ISSN

2460-030X

diperoleh dari website Dirjen Perimbangan Keuangan Pusat dan Daerah dan website resmi Pemerintah Daerah.

\subsection{Populasi Dan Sampel}

Populasi dalam penelitian ini adalah seluruh Kabupaten/Kota di Provinsi Jawa Barat yaitu sebanyak 26 Kabupaten/Kota. Data Populasi dalam penelitian ini adalah sebagai berikut:

Tabel 1 Populasi Penelitian

\begin{tabular}{|c|c|c|c|}
\hline NO & \multicolumn{3}{|c|}{ NAMA KABUPATEN/KOTA DI JAWA BARAT } \\
\hline \hline 1 & Kabupaten Sukabumi & 14 & Kabupaten Karawang \\
\hline 2 & Kabupaten Cianjur & 15 & Kabupaten Bekasi \\
\hline 3 & Kabupaten Bandung & 16 & Kabupaten Bandung Barat \\
\hline 4 & Kabupaten Garut & 17 & Kota Bogor \\
\hline 5 & Kabupaten Tasikmalaya & 18 & Kota Sukabumi \\
\hline 6 & Kabupaten Ciamis & 19 & Kota Bandung \\
\hline 7 & Kabupaten Kuningan & 20 & Kota Cirebon Bekasi \\
\hline 8 & Kabupaten Cirebon & 21 & Kota Depok \\
\hline 9 & Kabupaten Majalengka & 22 & Kota Cimahi \\
\hline 10 & Kabupaten Sumedang & 23 & Kota Tasikmalaya \\
\hline 11 & Kabupaten Indramayu & 24 & Kota Banjar \\
\hline 12 & Kabupaten Subang & 25 & 26 \\
\hline 13 & Kabupaten Purwakarta & & \\
\hline
\end{tabular}

Sampel yang digunakan dalam penelitian ini didapat dengan teknik pengambilan sampel Nonprobability Sampling dengan Sampling Jenuh. Peneliti menggunakan teknik sampling ini karena jumlah populasi sebanyak 26 Kabupaten/Kota.

\subsection{Operasionalisasi Variabel}

Tabel 2. Tabel Operasinalisasi Variabel

\begin{tabular}{|c|c|c|c|c|}
\hline VARIABEL & KONSEP VARIABEL & INDIKATOR & SKALA & QUANTUM \\
\hline $\begin{array}{l}X=\text { Potensi } \\
\text { Pajak } \\
\text { Daerah }\end{array}$ & $\begin{array}{l}\text { Potensi Pajak yaitu “ } \\
\text { Perhitungan teoritis } \\
\text { berapa jumlah pajak } \\
\text { yang mestinya } \\
\text { terhimpun dalam suatu } \\
\text { tahun dengan } \\
\text { memperhatikan } \\
\text { berbagai Variable.” } \\
\text { ( Nurmantu, 2003). }\end{array}$ & $\begin{array}{l}\Delta \text { Potensi } \\
\text { pajak t/ } \Delta \\
\text { potensi pajak } \\
\text { t-1 }\end{array}$ & Rasio & $\begin{array}{l}\text { Target } \\
\text { Pajak } \\
\text { Daerah }\end{array}$ \\
\hline
\end{tabular}




\begin{tabular}{|c|c|c|c|c|}
\hline $\begin{array}{l}\mathrm{Y} 1= \\
\text { Pendapatan } \\
\text { Asli Daerah }\end{array}$ & $\begin{array}{l}\text { "Pendapatan Asli } \\
\text { daerah, merupakan } \\
\text { pendapatan daerah } \\
\text { yang bersumber dari } \\
\text { daerah itu sendiri. } \\
\text { Termasuk dalam } \\
\text { pendapatan jenis ini } \\
\text { adalah pajak daerah, } \\
\text { retribusi daerah, hasil } \\
\text { pengelolaan kekayaan } \\
\text { daerah yang } \\
\text { dipisahkan, dan lain- } \\
\text { lain PAD yang sah." } \\
\text { (Deddi Nordiawan, } \\
\text { 2008:181). }\end{array}$ & $\begin{array}{l}\triangle \mathrm{PAD} t / \Delta \\
\text { PAD t-1 }\end{array}$ & Rasio & $\begin{array}{c}\text { LRA } \\
\text { (Laporan } \\
\text { Realisasi } \\
\text { Anggaran) }\end{array}$ \\
\hline $\begin{array}{l}\text { Y2 = } \\
\text { Kapasitas } \\
\text { Fiskal }\end{array}$ & $\begin{array}{lr}\text { Kapasitas } & \text { fiskal } \\
\text { sebagai kemampuan } \\
\text { suatu daerah untuk } \\
\text { meningkatkan } \\
\text { penerimaan dari } \\
\text { berbagai sumber } \\
\text { daya yang dimilikinya. } \\
\text { Compson dan Navratil } \\
\text { (1997: } 3-4)\end{array}$ & $\begin{array}{l}\Delta \text { Kapasitas } \\
\text { fiskal t / } \Delta \\
\text { Kapasitas } \\
\text { fiskal t-1 }\end{array}$ & Rasio & $\begin{array}{l}\text { IKF (Indek } \\
\text { Kapasitas } \\
\text { Fiskal) }\end{array}$ \\
\hline
\end{tabular}

\section{HASIL PENELITIAN DAN PEMBAHASAN \\ 4.1 Pengaruh Potensi Pajak Daerah (X) terhadap Pendapatan Asli Daerah $\left(\mathbf{Y}_{1}\right)$}

Karakteristik suatu daerah dengan daerah lain berbeda-beda, hal tersebut disebabkan karena perbedaan kekayaan dan sumber daya yang dimiliki daerah baik sumber daya alam, sumber daya manusia dan sumber daya ekonomi. Faktor pembeda tersebut digolongkan dalam faktor demografi, ekonomi, sosiologi, budaya, geomorfologi dan lingkungan yang berbeda-beda. Kekayaan daerah dapat tercermin dari Produk Domestik Bruto (PDRB). Perbedaan kekayaan daerah tersebut berdampak pada berbedanya potensi pendapatan yang bisa digali oleh daerah. Potensi pendapatan daerah bisa diperoleh dari sektor pajak, retribusi dan pengelolaan kekayaan daerah lainnya.

Jika melihat dari Produk domestik bruto dimana Kabupaten/Kota yang ada di Jawa Barat memiliki banyak produk unggulan, namun hal tersebut tidak menjamin besarnya potensi pajak daerah yang mestinya terhimpun dalam satu tahun. Sehingga kondisi tersebut bisa dilihat bahwa besarnya potensi pajak daerah belum seluruhnya tergali oleh pemerintah daerah. Sementara itu untuk Pendapatan Asli Daerah (PAD) Kabupaten/Kota di Jawa Barat menunjukan jumlah yang tergolong rendah dibandingkan dengan jumlah belanja daerahnya. Hal tersebut dapat dilihat dari Laporan Realisasi Anggaran Pemerintah Kabupaten/Kota di Jawa Barat dimana besaran PAD belum bisa menutupi 
belanja operasinya, serta besarnya dana perimbangan yang ditransfer oleh Pemerintah Pusat dan pemerintah Provinsi.

Mahmudi (2010:19), Manajemen pendapatan asli daerah tidak berarti exploitasi pendapatan asli daerah, tetapi bagaimana Pemda mampu mengoptimalkan penerimaan Pendapatan Asli Daerah sesuai dengan potensi yang dimilikinya. Menurut Hariyadi (2002), peningkatan pengelolaan pajak daerah dan retribusi daerah sesuai dengan potensinya akan memberikan tambahan Pendapatan Asli Daerah (PAD), akan tetapi sebaliknya apabila tidak diketahui potensinya akan membuat kerugian karena potensinya tidak dimanfaatkan maksimal.

Hasil penelitian ini, yang dilakukan terhadap 26 data potensi pajak daerah dan Laporan Realisasi Anggaran Kabupaten/Kota di Jawa Barat dari tahun 2012 sampai 2016, menunjukan bahwa potensi pajak daerah dan Pendapatan Asli Daerah (PAD) tiap tahunnya mengalami kenaikan. Kenaikan potensi pajak daerah tersebut menandakan adanya perbaikan penilaian (valutation) dan perhitungan (assesment) potensi pajak daerah. Sementara itu kenaikan Pendapatan Asli Daerah (PAD) menandakan bahwa upaya perpajakan semakin ditingkatkan untuk kontribusi pendapatan yang berasal dari sumber-sumbernya. Berdasarkan penelitian menggunakan analisis regresi sederhana, Pengaruh Potensi Pajak Daerah (X) terhadap Pendapatan Asli Daerah $\left(\mathrm{Y}_{1}\right)$ adalah berpengaruh hal ini sesuai dengan hipotesis maka dari itu hipotesis diterima, yang dimana terjadi kenaikan atau penurunan Potensi Pajak Daerah mempengaruhi Pendapatan Asli Daerah (PAD).

Hasil penelitian ini sejalan dengan penelitian yang dilakukan oleh Mario Hendry Wurangian (2013), Pendapatan Asli Daerah bersumber dari kapasitas penerimaan yang berasal dari pontensi ekonomi daerah, semakin besar potensi dapat menyebabkan penerimaan Pendapatan Asli Daerah semakin tinggi, karena banyak objek/pos -pos Pendapatan Asli Daerah yang dapat diciptakan guna ditarik penerimaannya oleh pemerintah daerah.Penelitian Agus Endro Suwarno dan Suhartiningsih (2008) dimana penelitian di lakukan di Kabupaten Sukoharjo juga menunjukan hal yang sama, dimana potensi pajak daerah harus terus digali dalam rangka meningkatkan pendapatan asli daerah.

\subsection{Pengaruh Potensi Pajak Daerah (X) Terhadap Kapasitas Fiskal $\left(\mathrm{Y}_{2}\right)$}

Kapasitas Fiskal merupakan kemampuan daerah dalam memperoleh pendapatan yang bisa digunakan untuk memenuhi kebutuhan dan belanja daerah dalam rangka menyediakan pelayanan publik. Tinggi dan rendahnya kapasitas fiskal tercermin dalam Indek Kapasitas Fiskal (IKF). Jawa Barat sebagai Provinsi yang berada di pulau Jawa memiliki Indek Kapasitas Fiskal dengan predikat rendah yaitu sebesar 0,30 . Kondisi tersebut juga dapat terlihat pada Indek Kapasitas Fiskal Kabupaten/Kota yang ada di Jawa Barat di mana masih didominasi oleh Indek Kapasitas Fiskal rendah.

Tinggi rendahnya kapasitas fiskal suatu daerah sangat tergantung oleh banyak faktor, salah satunya yaitu faktor kekayaan daerah. Kekayaan daerah ini merupakan potensi pajak yang bisa di manfaatkan dan dioptimalkan dalam rangka memperoleh sumber pendapatan.

Berdasarkan teori yang diungkapkan M. Aries Djaenuri (2012: 54), perubahan terhadap kekayaan daerah berpengaruh terhadap kemampuan keuangan daerah. Artinya bahwa naik atau turunnya kekayaan daerah yang diestimasikan 
dalam potensi pajak daerah akan berakibat pada naik atau turunnya kapasitas fiskal. Robert Simanjuntak (2003), semakin gencar daerah menghimpun penerimaan pajak dari sumber-sumbernya, semakin tinggi ukuran kapasitas fiskalnya, dan semakin rendah transfer yang akan diterimanya. Menurut Sirait (2009) bahwa kapasitas fiskal merupakan kemampuan pemerintah daerah menghimpun pendapatannya dari potensi yang dimilki. Dimana kapasitas fiskal sangat bergantung pada ada atau tidaknya serta mampu atau tidaknya mengelola potensi yang dimilikinya dalam hal ini adalah potensi pajak daerah.

Menurut Roberto Akyuwen (2013), kapasitas fiskal pada dasarnya menggambarkan kemampuan pemerintah untuk mengelola penerimaan dan membiayai pengeluarannya dalam rangka menjalankan tugas pemerintahan, pembangunan, dan pelayanan publik. Selain itu, karena dikaitkan dengan kemiskinan, maka kapasitas fiskal juga mengindikasikan kemampuan pemerintah daerah untuk mengatasi masalah pembangunan yang direpresentasikan oleh kemiskinan. Semakin mampu pemerintah di suatu daerah meningkatkan penerimaannya, serta pada saat yang sama mampu membatasi belanja pegawai dan mengurangi jumlah penduduk miskin, maka kapasitas fiskal yang bersangkutan akan semakin tinggi. Sebaliknya, jika pemerintah tidak mampu meningkatkan penerimaannya, membatasi belanja pegawai, dan menurunkan jumlah penduduk miskin, maka kapasitas fiskal akan rendah.

Berdasarkan hasil penelitian pengaruh potensi pajak daerah (X) terhadap kapasitas fiskal $\left(\mathrm{Y}_{2}\right)$ adalah tidak berpengaruh, hal ini sesuai dengan hipotesis maka hipotesis diterima, artinya apabila terdapat kenaikan potensi pajak daerah, kapasitas fiskal akan mengalami penurunan. Sampel data yang diambil dalam penelitian ini, yaitu 26 Kabupaten/Kota yang ada di Jawa Barat diperoleh temuan faktor-faktor apa saja penyebab potensi pajak daerah tidak berpengaruh terhadap kapasitas fiskal diantaranya sebagai berikut:

1. Perhitungan kapasitas fiskal menggunakan data pendapatan rill yang berhasil dihimpun selama satu tahun sehingga nilai tersebut belum mencerminkan kemampuan yang sebenarnya dan potensi yang sebenarnya dimiliki daerah. Selain itu, Pemerintah masih belum konsisten dalam menetapkan metode dan formula perhitungan kapasitas fiskal bagi daerah. Untuk mendukung pernyataan tersebut. maka di bawah ini disajikan metode dan formula perhitungan Kapasitas Fiskal :

2. Jumlah penerimaan Pendapatan Asli Daerah yang merupakan cerminan dari potensi daerah jumlahnya lebih kecil dibandingkan dengan belanja pegawainya. Tahun 2012, jumlah pendapatan asli daerah di 26 Kabupaten/Kota lebih kecil dibandingkan dengan belanja pegawainya. Tahun 2013, karena formula yang dipergunakan berbeda dari tahun sebelumnya maka tidak dapat diperbandingkan antara pendapatan asli daerahnya dengan belanja pegawainya. Untuk Tahun 2014, 2015 dan 2016 pendapatan asli daerah 26 Kabupaten/Kota jumlahnya lebih kecil dari pada belanja pegawainya. Untuk lebih memberikan gambaran mengenai perbandingan jumlah pendapatan asli daerah dengan belanja pegawai akan digambarkan dalam bentuk diagram. (Diagram terlampir).

3. Jumlah penduduk miskin sebagai indikator dari kapasitas fiskal terdata berada pada angka di atas satu digit atau ratusan ribu penduduk miskin. Hal tersebut 
memberikan dampak pada ukuran kapasitas fiskal Kabupaten/Kota di Jawa

Barat. Untuk lebih memberikan gambaran mengenai jumlah penduduk miskin

di bawah ini digambarkan dalam bentuk diagram, sebagai berikut:

Dari uraian di atas dapat dikatakan bahwa naik turunnya kapasitas fiskal Kabupaten/Kota yang ada di Jawa Barat bukan karena tinggi atau rendahnya potensi yang dimiliki tetapi lebih disebabkan karena Pemerintah daerah belum maksimal dalam me-manage belanja daerahnya dan kemampuan daerah dalam menekan penduduk miskin serta konsistensi metode dan formula yang digunakan dalam mengestimasi kapasitas fiskal daerah.

Hasil penelitian ini bertolak belakang dengan penelitian yang dilakukan oleh Estie Veraningsih (2009), untuk meningkatkan kemampuan keuangan daerah dapat dilakukan melalui upaya peningkatan PDRB perkapita, pengefektifan penerimaan pajak, pengembangan perekonomian daerah sesuai potensi daerah tanpa menitikberatkan pada salah satu sektor. Hasil yang berbeda ini dikarenakan perbedaan variabel yang mempengaruhi kapasitas fiskal dan wilayah penelitiaannya ada di Provinsi Jawa Timur.

\section{Kesimpulan}

Berdasarkan hasil analisis data dan pembahasan yang telah dijelaskan pada sebelumnya, maka penulis mengambil beberapa kesimpulan sebagai berikut:

1. Tujuan dari penelitian ini yang pertama adalah untuk membuktikan bahwa potensi pajak daerah memberikan pengaruh kepada Pendapatan Asli Daerah (PAD) di Kabupaten/Kota di Jawa Barat. Secara empiris terbukti, bahwa potensi pajak daerah berpengaruh terhadap Pendapatan Asli Daerah (PAD) di beberapa Kabupaten/kota di Provinsi jawa Barat, yang artinya apabila terjadi kenaikan dan penurunan potensi pajak daerah akan berpengaruh pada Pendapatan Asli Daerah (PAD).

2. Tujuan penelitian ini yang kedua adalah untuk membuktikan apakah ada pengaruh potensi pajak daerah terhadap kapasitas fiskal di Kabupaten/Kota di Jawa Barat. Secara empiris tidak terbukti, bahwa potensi pajak daerah berpengaruh terhadap Kapasitas Fiskal di Kabupaten/Kota di Provinsi Jawa Barat, yang artinya setiap kenaikan atau penurunan potensi pajak daerah tidak memberikan pengaruh terhadap kapasitas fiskal. 


\section{DAFTAR PUSTAKA}

Adisasmita, Raharjo. 2014. Pembiayaan Pembangunan Daerah, Edisi pertama, Yogyakarta: Graha Ilmu.

Akyuwen Roberto.2013.Kajian Akademis BPPK.Analisis Kapasitas Fiskal Kota Study Komparasi Kota Yogyakarta dan Kota Ambon, Jakarta: Kementrian Keuangan RI Badan Pendidikan dan Pelatihan Keuangan.

Arikunto.2006. Prosedur Penelitian Suatu Pendekatan Praktik, Jakarta: Rineka Cipta.

Azis, Azhari. 2015. Perpajakan di Indonesia, Jakarta: PT.Rajagrapindo Persada.

Bambang Supomo, Nur Indriantoro. 2011. Metodologi Penelitian Bisnis. Yogyakarta: BPFE.

Davey KJ. 1983. Finanacing Regional Government, International Practice and Their Relevance to the Third World. Chichester: John Willey.Djaenuri, Aries, H. 2012. Hubungan Keuangan Pusat dan Daerah, Edisi pertama, Bogor: Ghalia Indonesia.

Gurwitz Aaron Samuel.1979. The Measurement of Fiscal Capacity. Washington, DC: Rand Corporation.

Hariyadi.2002. Analisis Pengaruh Fiscal Stress Terhadap Kinerja Keuangan Pemerintah Kabupaten/Kota Dalam Menghadapi Pelaksanaan Otonomi Daerah (Suatu Kajian Empiris di Propinsi Jawa Timur). Simposium Nasional V Semarang 5-6 September 2002

Mahmudi. 2010. Manajemen Keuangan Daerah, Jakarta: Erlangga.

Majdi. 2007. Perencanaan Pembelajaran. Bandung: Remaja Rosdakarya

Mardiasmo.2002. Perpajakan. Yogyakarta: Andi Offset.

Mickiewicz ,Gerry.2006 "Inequality, Fiscal Capacity and the Political Regime: Lessons from the Post-Communist Transition". William Davidson Institute Working Paper Number 831. The William Davidson Institute at the University of Michigan.Navratil, Compson. 1997 "An Improved Method for Estimating the Total Taxable Resources of the States". Research Paper No. 9702.

Nordiawan, Deddi. 2012. Akuntansi Pemerintahan. Jakarta: Salemba Empat Nazir, Muhamad. 2003. Metode Penelitian Bisnis.Yogyakarta:BPFE

Nurmantu. Safri. 2003. Pengantar perpajakan.Jakarta: Granindo.

Sekaran, Uma.2014. Research Methods For Business. Jakarta:Salemba Empat. Sidik. 2002. Perimbangan Keuangan Pusat dan Daerah sebagai Pelaksanaan Desentralisasi Fiskal (antara Teori dan Aplikasinya di Indonesia). Seminar "Setahun Implementasi Kebijaksanaan Otonomi Daerah di Indonesia".

Simanjuntak, Robert.2003. Kebutuhan Fiskal, Kapasitas Fiskal dan Optimalisasi Potensi PAD. Jakarta: LPEM FEUI.

Sirait, Robby Alexander. (2009). Desentralisasi Fiskal-Dana Alokasi Umum.

Sriyana,Jaka. 2012. Dinamika Kinerja Fiskal Indonesia. Yogyakarta: UII Press.

Sugiyono. 2010. Metode Penelitian Kuantitatif Kualitatif dan R\&D.Bandung: Alfabeta. Suhartiningsih. Suwarno Endro Agus.2008 Efektifitas Evaluasi Potensi Pajak Daerah Sebagai Sumber Pendapatan Asli Daerah.Surakarta: FE UMS.

Umar, Husein. 2005. Metode Penelitian: Salemba Empat. 


\section{ISSN}

Jurnal Akuntansi Bisnis dan Ekonomi

2480-030X

Volume 4 No. 2, September 2018

Undang- Undang No. 23 tahun 2014 tentang Pemerintahan Daerah.

Undang-Undang Nomor 17 Tahun 2003 tentang Keuangan Negara.

UU No. 33 tahun 2004 tentang perimbangan keuangan antara pusat dan daerah.

Peraturan Menteri Keuangan No. 37/PMK.07/2016 tentang Peta Kapasitas

Fiskal.

Peraturan Menteri Dalam Negeri No.13 tahun 2006

Warsito. 2001. Perananan dan Strategi Peningkatan PAD. Jakarta: Rajawali Grafindo. Wuragian.Hendry.Mario.2013. Analisis Potensi Pajak Daerah Kabupaten Minahasa. Manado : Jurnal EMBA 